Erratum

\title{
Estradiol Supplementation Helps Overcome Central Leptin Resistance of Ovariectomized Mice on a High Fat Diet
}

R. Matyšková, B. Železná, J. Maixnerová, D. Koutová, M. Haluzík, L. Maletínská

Hormone and Metabolic Research 2010; advance online publication: DOI: 10.1055/s-0029-1243250

In Table 1 of the original article the values for triglycerides $(\mathrm{mg} / \mathrm{dl})$ are incorrect. The correct values are: $58.2,66.1,70.7$ and $68.8 \mathrm{mg} / \mathrm{dl}$. 